\title{
Relation Between Creativity and Economy in the Creative Economy (A Case Study on Acapella Mataraman Musical Parody Community)
}

\section{Firmansah}

Graduate School of Indonesia Institute of the Arts Yogyakarta email: firmansah_appe@yahoo.com

\begin{abstract}
The aim of this study is to determine and to explain the relationship between creativity and economics. This phenomenon can be seen through the performing arts community in the era of government policy on creative economy which established in 2007. As the qualitative study, this study used case study approaches to Acapella Mataraman community .This study also used the economic concept art by Ruth Towse. The research finding of this study is the creative economy logic of the government can create important factors of increasing the level of creativity. So that Pardiman as the intellectual and major figure in Acapella Mataraman community is able to classify his creativity on consumer's price demand. In addition, the non-profit aspect also can be applied by Pardiman as the Acapella Mataraman community promotion in the performing arts market.
\end{abstract}

Keywords: creativity, economic, creative economy, and musical parody.

\section{INTRODUCTION}

The economic issue is the universal problem of all societies in the world. Many countries solved the economic problem through creative economy program. In 2007, Indonesian government also took part in creative economy programs. Indonesian government version of creative economy programs include sectors which are expected to improve the livelihoods of the social community. In order to optimize that policy, it requires collaboration between the intellectual, business and government that is called triple helix. Government as facilitator and regulator not only provides convenience for the marketing of products in each sector but also provides ease information and knowledge for the society improvement, so this program could be effective.

Performing art sector also got the major impact of that policy. That policy indirectly altered the patterns of production and consumption the art of performing. New pattern of performing art production has the purpose of acquiring improvement for economy, in creative economy, any product of art is considered as the commercial product. It can be assumed from this case that the economy has an important role in enhancing creativity. The higher cost of consumer demand, the higher level of creativity the artist do work of art. This assumption will be verified in this study through Acapella Mataraman community 
in Yogyakarta using economic perspective on the art of Ruth Towse and Daniel bell on the post industrial society.

Acapella Mataraman is a musical parody community that is in the performing arts business. Pardiman as the role figure of this community adjust the creativity according to the consumers demand. Pardiman's roles not only determine Acapella Mataraman existence in performing art world but also differentiated Acapella Mataraman from other art communities. It also supported the strategy in producing, promoting and marketing the products of his art through Mataraman Acapella. In the era of the creative industries, the triple helix pattern can be seen between Pardiman (intellectual), Acapella Mataraman (Business) and the Government. The balance of triple helix in Acapella Mataraman community becomes the main reason why this study chose that community.

According to Ruth Towse ( 2011 ), individual creativity in industry cannot be improved on only investment in training but economic factors also have the role affecting creator of art on how to be creative. This perspective helps Pardiman as a major figure in the musical parody Acapella Mataraman community in assessing the creative process. To complete the concept of Ruth Towse, this study uses the perspective of Daniel Bell on the post-industrial society. Daniel Bell (1973) stated that professional class is the heart of the post industrial society. The shifting of knowledge and the ease of information had economic impact to the society. Professional class in this case is referred to Pardiman as Intellectual. Utilizing the knowledge and information in his work makes Pardiman producing and marketing his works through Acapella Mataraman creative community. Postindustry study is still relevant in Indonesia because of changes in patterns of production and consumption and also impact of the knowledge and information development. By using these two concepts above, This study is expected to find a dominant factor in the creative process Pardiman in the era of the creative industries.

\section{Research Questions}

1. Does economic factor become primary motivation in the creative process of Pardiman?

2. Why Economic factor is important in his creative process?

3. How the economic factor affect the creative process of Pardiman?

\section{RESEARCH METHOD}

This study used qualitative method through the case study approach. The steps performed in the research include: preliminary observations on the creative and performing arts industry. After that choosing Acapella mataraman as the case example of relationship between economy and creativity. After a further discussion, Pardiman as a major figure in the community willing to be the main source of this study. This study used triangulation as the process of using different multiple data sources but in the same subject by comparing information from one 
data source to the others. By using triangulation, this study is able to identify the reality of different views in the focus of discussion. The last step is analyzing the data using the concept of Ruth Towse and Daniel Bell.

\section{RESULTS}

\section{Government policy on creative economy}

The relationship between creativity and the economy is not effective without government support on the policy of creative economy. The creative economy also strongly supported by the Act NO.32 of 2004 on regional autonomy. In 2012, Yogyakarta became one of the cities listed to UNESCO as the creative city-based on local culture (http://tempo.com/). Because of that, Yogyakarta had opportunity to develop fourteen creative economy sectors (including performing art sector) with economic agglomeration system. Towse (2010) stated that the people in creative city has the benefit from the festival excitement, so the demand for performing art also increases. According to UNESCO (Suryana, 2013) this creative culture formed by the combination of product and commercialization. Although based on the local culture, every product of the creative economy is commercial product in the form of goods and services which include marketing, sales, and promotion (Suryana, 2013).

Pardiman as an intellectual in the creative economy creates the creative ideas to make the art products which have better the economic values. On the other hand, the art products increase government tax revenues through tourism. According to Suryana (2013) Creative economy contributes positively to increase the national income. In the education field, Pardiman creates creative mindset to young generations as the support to the government's policy. Pardiman activities as the intellectual are lecturing art in one of university in Yogyakarta and becoming speaker in SMKI (High school of traditional art) for the students' practical work activities. The aim of practical work activities is to prepare student to face the real performing art world, especially in Karawitan (www.worldcangkem.com/). Pardiman activities in education field can be inferred as the collaboration between the intellectual and the government in preparing the next generations as the intellectual or the business in triple helix. These patterns are in the employment dimension of post-industrial society. According to Bell (1973), the professional is needed in the post-industrial society, the professional in that term is referred to Pardiman as the intellectual.

The increase in national income will have impact on every sector of creative industries. It changes not only the product but also on the art services in the performing arts sector. Total cost and demand for services increase with the change of knowledge and information. Bell (1973) stated that the change in knowledge and information have the consequences on increasing demand for greater services and this change is the characteristic of the economic dimensions of post-industrial society. The post-industrial characteristics give better opportunity to the performing arts communities in Yogyakarta to get high 
economic benefit from their performances. One of the creative community in Yogyakarta which get this benefit is Acapella Mataraman. This community always performs in the government official events. Acapella Mataraman also got involved in the promotion of cultural tourism in Yogyakarta, one of them is Taman Sari (water castle) promotion. (http://travel.kompas.com/).

According to Bell (1973) post-industrial society is the global community (globalization) with the sophisticated technology of information and knowledge that create world culture. This technological advance is able to create common paradigm in the world about the type of performing art that worth watching. The policy of the creative economy based on local culture make the artists and the performing arts lovers, especially teenagers in Yogyakarta enjoy the local performing arts like Acapella Mataraman which combines modern and traditional music. According to Ruth Towse (2010) even though digitalization had changed, economic factor became very significant features in performing art which depends on the government policy about the performing arts market in every country. This circumstances fit to Bell concept that stated government has a greater role in the economic dimensions of post-industrial society than the market to determine the decision (1973).

\section{Creative process of Pardiman, between the intellectual and the role figure in Acapella Mataraman}

The main "power" to gain more economic values in creative economy is creativity. The fourteen sectors of creative industries including performing arts also get the impact of this circumstance. According to Deliege and Wiggins (2006) emergence creativity consists of two factors: intrinsic and extrinsic. Pardiman as a major figure in the musical parody community, Acapella Mataraman is intellectually capable of processing both two factors into the art works. His ability in making music composition, his existence in the world of performing arts in 1981-2014 and also high intensity in the work become intrinsic factor of Pardiman. Pardiman has extrinsic factors like other artists, such as political situations, social and religious issues. However, the factors which increase Pardiman's creativity were the economic situation that led his family into the bad situation in 1998-2000 and internal conflict in Acapella Mataraman. As stated by Simonton (1987, Hargreaves \& North: 2003) that creativity will increase if the composer is under pressure as a result of the changes in life.

Both factors are the main sources of his creativity. Although he had to stop for several years, because of those intrinsic factors. To bring back Acapella Mataraman on the performing art market, Pardiman must lose his loyal fans. Educating the youth, including his Gamelan (traditional Javanese instruments) pupils and they are trained to be the new generations in Acapella Mataraman. Using the youth as the member of the community is expected to get fans from the old generations and the young as well. Comosing traditional Nusantara music with acapella technique, poetic lyric, attractive costumes, choreography, and humor distinguish Acapella Mataraman from other performing art communitiesp. Although every 
music in Acapella Mataraman is created with minimum melody, the fans still enjoy the rhythm and timbre. This case fits to the concept Simonton (1991, Hargreaves \& North: 2003) that stated: those who lived in the musical environment will produce the original art work with minimal melody but it has high scores on the accessibility to the music lovers.

The power of production sources in creative economy will be more effective, if the government issues the policy of creative industries. Triple helix as the pillar of the creative economy change the pattern of Indonesian performing arts market through easy access to information and knowledge. Pardiman as the intellectual supports the policy through the youth training to form creative mindset. As a major figure, Pardiman always participates in government programs to promote cultural tourism in Yogyakarta through performing musical parody Acapella Mataraman. Maximizing the role of major figure as the intellectual creates the positive image to the domestic and foreign fans.

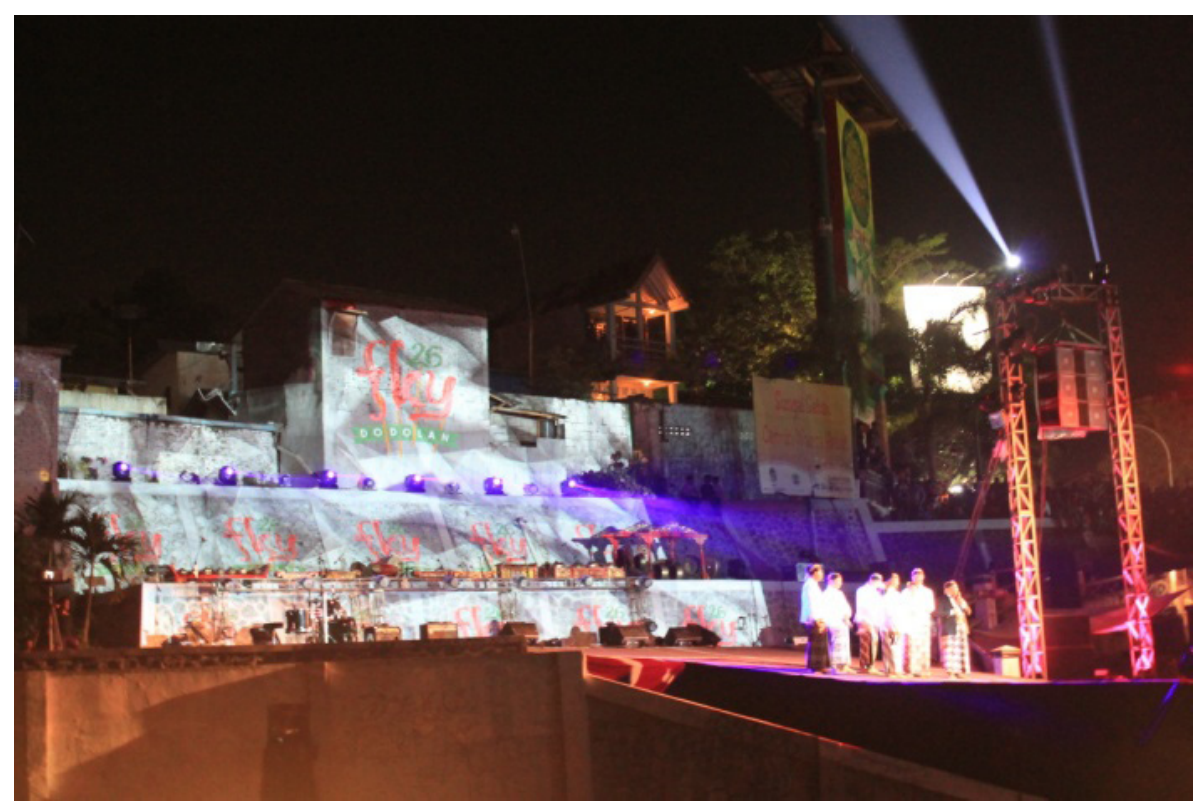

Pic1. Acapella Mataraman performances in FKY $26^{\text {th }}$

The huge number of Acapella Mataraman fans is the proof that the demand of performing art services also increase. As stated by Towse (2010) the great number of fans who are willing to pay for the performing art show is the indicator of greater performing art demand. However, It also has the economic implication to increase creativity. High cost of production is offered for business and the low cost for the non-business consumers. Acapella Mataraman considers the commercial and non-commercial factors in determining the price. This strategy aligned with the opinion of Ruth Towse (2010) regarding the pricing of the balancing factor of commercial and non-commercial.

The show location also determines the price. The lower price is offered when the show is held in Yogyakarta and the higher The lower price is offered when the show is held outside Yogyakarta. Pricing also related to the number of 
players in a show. Usually, Pardiman must pay additional cost when Acapella Mataraman performed in art appreciation show. This additional cost must be paid because production fixed cost allocation is insufficient to pay the players. To get profit, Pardiman provides accessories, clothes, and Acapella Mataraman official merchandise. In the performing arts economy Towse (2010) explained that: in order to gain maximum profit, the goods and services should complete each other.

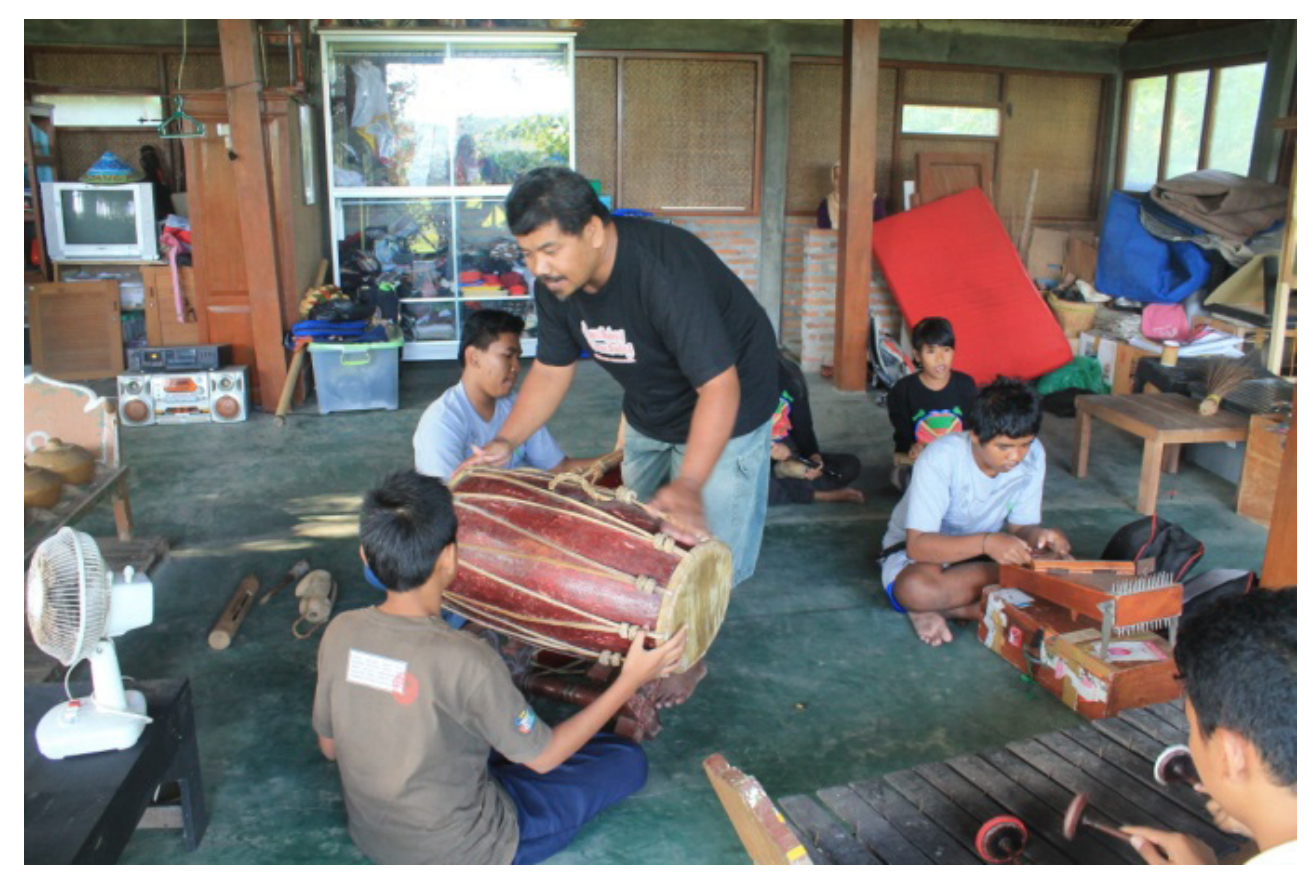

Pic 2. karawitan rehearsal process by Pardiman

Acapella Mataraman is considered as profit community but this community is still aware about the non-profit aspect. Non-profit service is the additional cost. Pardiman termed it as 'absen publik' (public absent) or Towse (2010) conceptualized as 'social efficiency'. This strategy is part of the promotion, This 'absen publik' is expected to gain the service consumers from the higher economic level. Another way to promote Acapella Mataraman is through the website, so the fans and service consumers are able to get information through the site.

Acapella Mataraman doesn't make particular segmentation for its fans and service consumers. According Pardiman, particular segmentation will reduce the production and income. As explained earlier, the absence of particular segmentation makes the different pricing. According to Towse (2010) this is price discrimination. Thorsby (Towse, 2010) stated that differentiation will have impact on the quality of services. It is very complex to measure these things in the creative industries, there is a strong interaction between artistic and economic factors. Cowen and Tabarrock (2000, 2011), Cellini and Cuccia (2003.2011) also stated that the artists in the industry who pursue aesthetic satisfaction, fame, livelihood, eventually learned to adjust the level of creativity to gain greater profit. 


\section{CONCLUSION}

As stated above, the relationship between The Government, Acapella Mataraman, and Pardiman is considered as the triple helix. So, it can be inferred that economic factors play important role in increasing the level of creativity. Government policy of creative economy increased national income. The policy also changed the pattern of performing arts market. The change is characterized by the greater demand for services and the cost of production. This phenomenon made Pardiman classifying level of creativity according to the consumers cost. There is no specific segmentation in the performing arts services. If the consumers demanded new works, the cost will be offered high. On other hand, Pardiman implemented non-profit aspects to promote Acapella Mataraman. By performing for the low cost consumers is expected to gain the service consumers from the higher economic level.

\section{REFERENCES}

Bell, Daniel, (1973), The Coming of Post-Industry. A Venture in Social Forecasting, New York: Basic Book.

Denzin, Norman K \& Lincoln Yvonna S (2010), The Sage Handbook Of Qualitative Reaserch Third Edition, California: Sage publication.

Deliege, Irena \& Wiggins, Geraint, (2006), Musical Creativity, Multidiciplinary Research In Theory and Practice, New York : Psychology Press.

Hargreaves, David J \& North, Adrian C, (2003), Social Psychology Of Music. Oxford: University Press.

Suyana, (2013), Ekonomi Kreatif Ekonomi Baru, Mengubah Ide dan Menciptakan Peluang, Jakarta: Salemba Empat.

Towse, Ruth, (2010), A Text of Cultural economic, Cambridge University Press.

Towse, Ruth, (2011), A Handbook Of Cultural Economic Second Edision, Edward Elgar.

\section{Electronic Sources}

http://travel.kompas.com/read/2014/01/04/0920504/Membangun.Pariwisata.DIY. Harus.Cerdas

www.worldcangkem.com/guestbook

http://www.tempo.co/read/news/2013/08/03/114502138/Empat-Kota-IndonesiaKandidat-Kota-Kreatif-Unesco 